\title{
ARTICLE \\ Two new overlooked bee species from Spain (Hymenoptera: Anthophila: Andrenidae, Apidae)
}

\author{
Thomas J. WooD ${ }^{1}$
}

Wood, T. J. (2022). Two new overlooked bee species from Spain (Hymenoptera: Anthophila: Andrenidae, Apidae). Osmia, 10: 1-12.

https://doi.org/10.47446/OSMIA10.1

\begin{abstract}
Spain has a large, species-rich bee fauna, but despite a long history of study, new species continue to be discovered at a rapid rate. New collections made during an expedition have revealed the existence of two additional species: Andrena (Taeniandrena) contracta spec. nov. is described from the high-altitude zone of the Sierra Nevada (Granada), and Nomada halophila spec. nov. is described from saline lagoons in Málaga province, where it is a parasite of the recently described Andrena (Notandrena) juliana WOOD, 2021. These findings emphasise the need to investigate unusual or understudied habitats in order to fully document the rich Spanish bee fauna.
\end{abstract}

Keywords $\mid$ Andrena $\cdot$ Nomada $•$ Sierra Nevada • Iberian endemic species • taxonomy • montane habitat

Deux espèces d'Espagne auparavant négligées (Hymenoptera : Anthophila : Andrenidae, Apidae)

Résumé

L'Espagne présente une faune d'abeilles diversifiée riche en espèces. Cependant, malgré de nombreuses études historiques, de nouvelles espèces continuent d'être régulièrement découvertes. De nouvelles captures réalisées lors d'un voyage en Espagne ont révélé l'existence de deux nouvelles espèces: Andrena (Taeniandrena) contracta spec. nov. est décrite dans la zone de haute altitude de la Sierra Nevada (Grenade), et Nomada halophila spec. nov. est décrite dans des lagunes salines de la province de Málaga où elle parasite les nids de l'espèce récemment décrite Andrena (Notandrena) juliana Wood, 2021. Ces découvertes soulignent le besoin de prospecter dans des habitats peu communs ou moins étudiés afin de connaître entièrement la riche apidofaune d'Espagne.

Mots-clefs $\mid$ Andrena $\cdot$ Nomada $\cdot$ Sierra Nevada $\cdot$ espèce endémique ibérique $\cdot$ taxonomie $\cdot$ habitat montagnard

Reçu • Received | 25 October 2021 || Accepté • Accepted | 11 February 2022 || Publié (en ligne) • Published (online) | 14 February 2022 Reviewers | F. J. ORTIZ-SÁNCHEZ • J. SMIT || http://zoobank.org/92C723FF-C925-4A8F-8E16-071DCDD12C60

\section{INTRODUCTION}

The bee fauna of Spain has a long history of study, and contains almost 1,100 species (ORTIZ-SÁNCHEZ, 2020). Though it has received much attention in a general sense, several corners of the country are under-visited and understudied. This is to be expected given its large surface area, the presence of numerous and extensive mountain chains that define the Iberian Peninsula, and the varied habitat types that exist between them.

One mountain of particular importance is the Sierra Nevada in south-eastern Spain which has an extremely high level of endemism for plants (BUIRA et al., 2020) and insects (RUANO et al., 2013). One endemic bee species and six endemic bee subspecies are known to exist there (MICHEZ \& EARDLEY, 2007; ORTIZ-SÁNCHEZ et al., 2013; ORTIZ-SÁNCHEZ \& PAULY,
2017; GHISBAIN et al., 2021), but it has received relatively little attention to date from Andrena FABRICIUS, 1775 specialists. Andrena is a huge species-rich genus (GUSENLEITNER \& SCHWARZ, 2002) that has recently been the focus of taxonomic study in Iberia (WOOD et al., 2020; WoOD et al., 2021), revealing the presence of seven overlooked or cryptic species; there is therefore a strong possibility of undocumented endemism on the Sierra Nevada for this genus.

As part of a collecting expedition in Spain during 2021 to study and better document the Iberian Andrena fauna, two new bee species were discovered in unusual habitats, one high in the alpine zone of the Sierra Nevada, and one in saline lagoons in the province of Málaga. They are described herein.

[TJW] Laboratory of Zoology, University of Mons, Avenue du Champs de Mars 6, B - 7000 Mons, Belgium • thomasjames.wood@umons.ac.be

(D) https://orcid.org/0000-0001-5653-224X • ZooBank http://zoobank.org/670C3E36-1D28-4FCA-887C-91D6116E6F9C

Osmia est une revue en libre accès publiée par l'Observatoire des Abeilles (France) sous licence Creative Commons Attribution International CC BY 4.0 qui autorise la reproduction et la diffusion du document, à condition que la source soit explicitement citée.

Osmia is an open-access journal published by the Observatory of Bees (France) under Creative Commons Attribution International License CC BY 4.0 which allows the reproduction and distribution of the document, provided the source is explicitly cited.

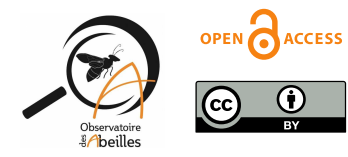




\section{MATERIAL AND METHODS}

Morphological terminology follows MICHENER (2007). The abbreviations $\mathrm{A}$ and $\mathrm{T}$ are used for antennal segments and metasomal terga, respectively. Specimens were measured from the vertical plane of the front of the head to the tip of the metasoma. Photographs were taken using an Olympus EM1 Mark II with a $60 \mathrm{~mm}$ macro lens. Close-ups were taken with the addition of a Mitutoyo M Plan Apo 10X infinity corrected objective lens or a Lomo 3.7x objective lens in combination with an Olympus M.Zuiko $2 x$ teleconverter lens, a $10 \mathrm{~mm}$ Kenko DG extension tube, and a Meike MK-P-AF3B $10 \mathrm{~mm}$ extension tube. Photographs were stacked using Zerene Stacker ver. 1.04 (Zerene Systems, USA) and plates were prepared in GNU Image Manipulation Program (GIMP) ver. 2.10. Post-processing of some images was made in Photoshop Elements (Adobe Systems, USA) in order to improve lighting to highlight specific characters.

Where available, pollen was removed from scopae of female Andrena and analysed by light microscopy in order to investigate their dietary preferences following the method of WOOD \& ROBERTS (2018). Dietary classification follows MÜLLER \& KUHLMANN (2008).

\section{Abbreviations}

JSC = Jakub STRAKA Collection, Prague, Czech Republic OÖLM = Oberösterreichisches Landesmuseum, Linz, Austria TJWC = Thomas James WoOD Collection, Mons, Belgium UMONS = Laboratory of Zoology Collection, University of Mons, Mons, Belgium.

\section{RESULTS}

\section{Andrena (Taeniandrena) contracta Wood, spec. nov.}

\section{roo:ank http://zoobank.org/2DC6DD80-3B59-49F1-B3DA-} B046288E8148

Holotype. Spain: Granada, Sierra Nevada, Puerto de La Ragua,

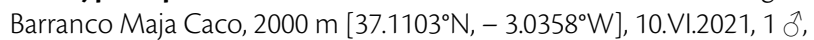
leg. T. J. WoOd. OÖLM.

Paratypes. Spain: Granada, Sierra Nevada, Puerto de La Ragua, Barranco Majá Caco, 2000 m [37.1103N, - 3.0358 W], 10.VI.2021, 10 ổ, 9 q 9 , leg. T.J. Wood, OÖLM/TJWC. Sierra Nevada, Trevélez to Refugio La Campiñuela, 1700-2400 m, 14.VI.2021, 2 ôे, leg. T. J. Wood, TJWC. Sierra Nevada, Trevélez, Refugio La Campiñuela, 2400

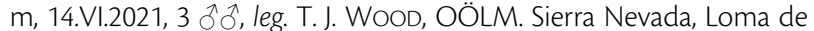
Cauchiles, 2600 m, 1.VII.2021, 1 q, leg. T. J. WoOD, TJWC. Sierra Nevada, b. [bei] Granada, 2300 m, 4.VII.1971, 3 ổ leg. V. HAESELER, OÖLM.

\section{Description}

\section{Female}

Body length: $13-14 \mathrm{~mm}$ (figure 1). Head: 1.3 times wider than long (figure 2). Clypeus dark, flattened over most of its area, densely and mostly uniformly punctate with exception of raised central impunctate line, punctures separated by 0.5-1 puncture diameters, becoming slightly denser apically; underlying surface shagreened, dull basally, shagreenation becoming weaker apically, apical margin weakly shining. Face below antennal insertions and lower half of gena with light whitish-yellowish hairs, not exceeding length of scape, becoming light brown on upper half of gena, scape, frons, and vertex. Antennae dark, $\mathrm{A} 3=\mathrm{A} 4+5$. Foveae broad, occupying almost all area between lateral ocellus and top of compound eye, filled with short brown hairs. Ocelloccipital distance equals 1.5 diameter of lateral ocellus. Mesosoma: Scutum densely punctate, punctures separated by $0.5-1$ puncture diameter, becoming sparser centrally and posteriorly, underlying surface shagreened and dull, becoming weaker centrally and posteriorly, here weakly shining (figure 3). Scutellum with sparser punctures separated by 1 puncture diameter, shagreenation weaker, generally shining. Episternum and propodeum with dense raised reticulation, underlying surface dull, propodeal triangle weakly indicated by change in sculpturing, becoming noticeably finer, centrally with similar reticulation strength to lateral parts of propodeum. Scutum and scutellum with short, orange-brown hairs, episternum with longer whitish-yellowish hairs, becoming orange-brown on propodeum. Legs dark, hind tibia partially and hind basitarsi entirely lightened orange, general pubescence whitish, becoming more orange apically; flocculus and femoral scopae whitish, tibial scopa orange (figure 4). Wings hyaline, venation dark orange, nervulus strongly postfurcal. Metasoma: Terga dark, finely shagreened and weakly shining, very narrow apical part of marginal areas lightened semi-translucent brown (figure 4). Terga very densely and evenly punctate, punctures separated by $<0.5$ puncture diameters, density becoming lower on tergal margins, punctures here separated by 1 puncture diameter, weaker and less pronounced. Tergal margins strongly depressed, most visibly those of T2-4. T1 laterally with whitish hair patches, T2 with broadly interrupted apical hair band, T3-4 with complete or nearly complete hairband. Remaining tergal surface covered with short, fine whitish to ferruginous hairs visible when viewed obliquely or in profile. Terminal fringe of $T 5$ and hairs flanking pygidial plate golden, pygidial plate rounded, flat, without raised margin.

\section{Male}

Body length: $12-13 \mathrm{~mm}$ (figure 5). Head: 1.3 times wider than long (figure 6). Clypeus dark, flattened over most of its area, densely and uniformly punctate with exception of shining impunctate central line, punctures separated by $<0.5$ puncture diameters; underlying surface weakly shagreened, shining, particularly apically. Face, gena, vertex, and scape with long white hairs, longest exceeding length of scape. Antennae dark, A3 subequal to A4. Ocelloccipital distance slightly exceeding 1 diameter of lateral ocellus. Mesosoma: Scutum evenly punctured with shallow punctures, punctures separated by 1 puncture diameter, underlying surface evenly shagreened, dull (figure 7). Scutellum with weaker shagreenation, weakly shining. Episternum and propodeum structurally as in female, 

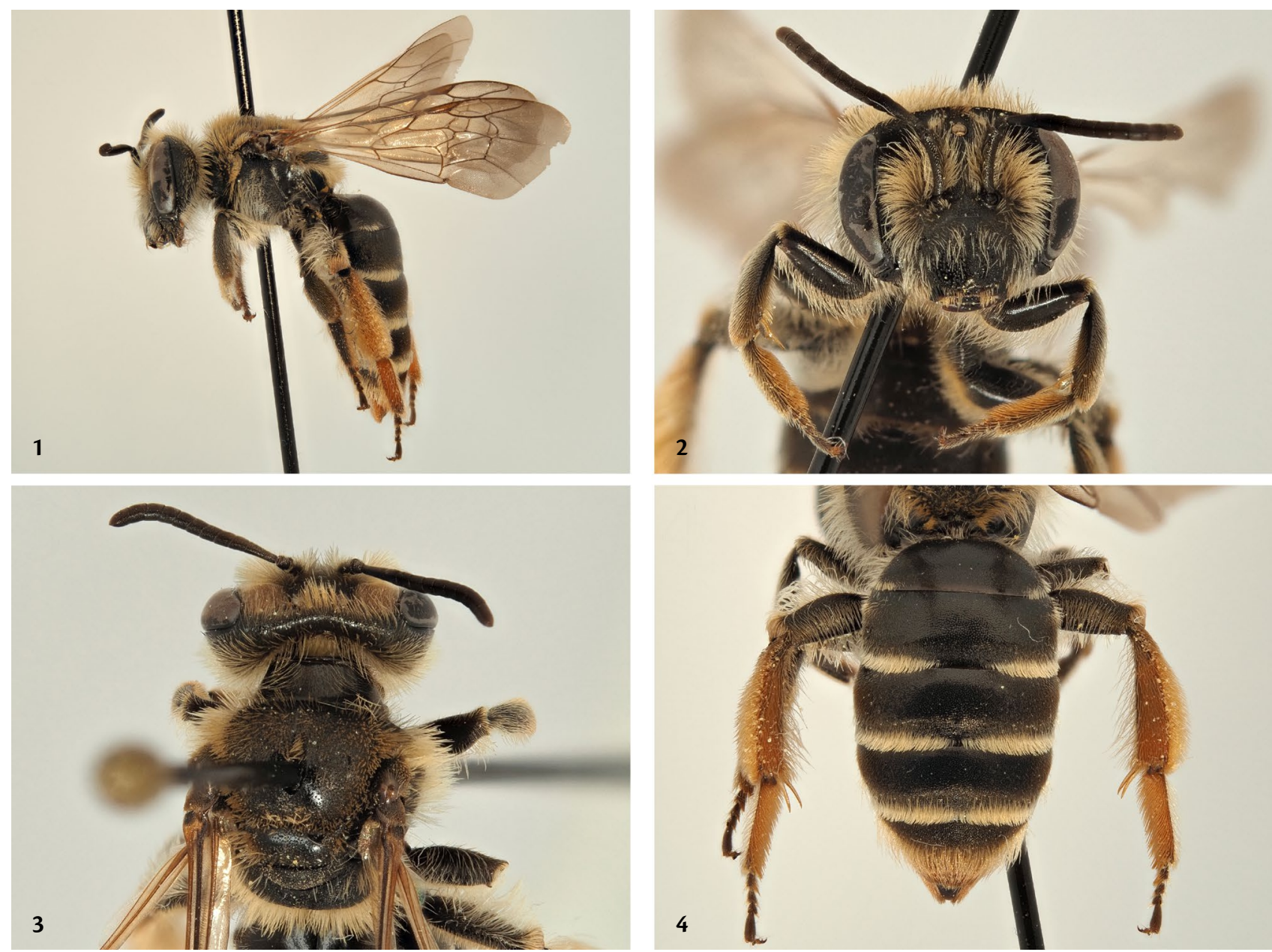

Figures 1-4. Andrena contracta spec. nov. 1. Female profile. 2. Female face. 3. Female scutum. 4. Female terga. Photos T. J. Wood.

entirely covered in long whitish-yellowish hairs, longest exceeding length of scape. Legs uniformly dark, pubescence whitish-yellowish. Wings as in female. Metasoma: Terga dark, very narrow apical part of marginal areas lightened semi-translucent brown, densely and evenly punctate, punctures separated by 1 puncture diameter (figure 8 ). Tergal margins strongly depressed, this becoming stronger apically. T2-5 with whitish hairbands, interrupted on T2, complete on T3-5. Genital capsule rounded oval in dorsal view, gonocoxa with inner margins parallel, apically produced into short, weakly pointed teeth (figure 9). Penis valve narrow, occupying less than $1 / 3$ of space between inner margin of gonostyli, outer margins broadly parallel, in basal half weakly concave. Gonostyli evenly rounded, spatulate, outer face covered with fine short hairs.

\section{Diagnosis}

Andrena contracta can easily be placed in the subgenus Taeniandrena HEDICKE, 1933 because of the evenly flattened clypeus. The most appropriate comparison species is Andrena intermedia THOMSON, 1870. Note this taxon is variable across its range, so the diagnosis is written with reference to its form and appearance in Iberia.

Females are almost indistinguishable, sharing the same densely and finely punctured terga, these being finely shagreened and hence weakly shining, complete or nearly complete hair bands on T3-5, slightly shiny apical margin of the clypeus, and light golden terminal fringe. Andrena contracta females can be separated by the greater density of the tergal punctures and the more strongly depressed tergal margins, but this requires comparative material in order to appreciate.

Males both have $A 4$ exceeding $A 3$ in length, but the principal difference in the male sex is in the radically different genital capsule. Here, A. contracta males (figure 9) have the gonocoxa with pronounced apical teeth, the penis valve is narrow and lacks lateral projections, and the apical part of the gonostyli is short and evenly rounded. In contrast, A. intermedia males (figure 10, specimen from Sierra Nevada, El Dornajo, $1700 \mathrm{~m}$ ) lack gonocoxal teeth, have a penis valve that is grossly inflated with weak lateral projections subapically, and the apical part of the gonostyli is elongated with an obtuse inner angle. The unique genital capsule allows for confident separation of $A$. contracta from all West Palearctic Taeniandrena.

\section{Ecology and distribution}

This species is found in the high-altitude alpine zone of the Sierra Nevada, between 2000-2600 m, and possibly higher, but no collections were made in these areas. It is found in near-sympatry with $A$. intermedia which can be found on and around the Sierra Nevada between 1200-2300 m, as well as in the nearby Sierra de Baza (see other material examined), most typically inhabiting the subalpine zone at or below the treeline (figure 11). The presence of $A$. intermedia was a surprise, as it has not previously been reported in Spain from 

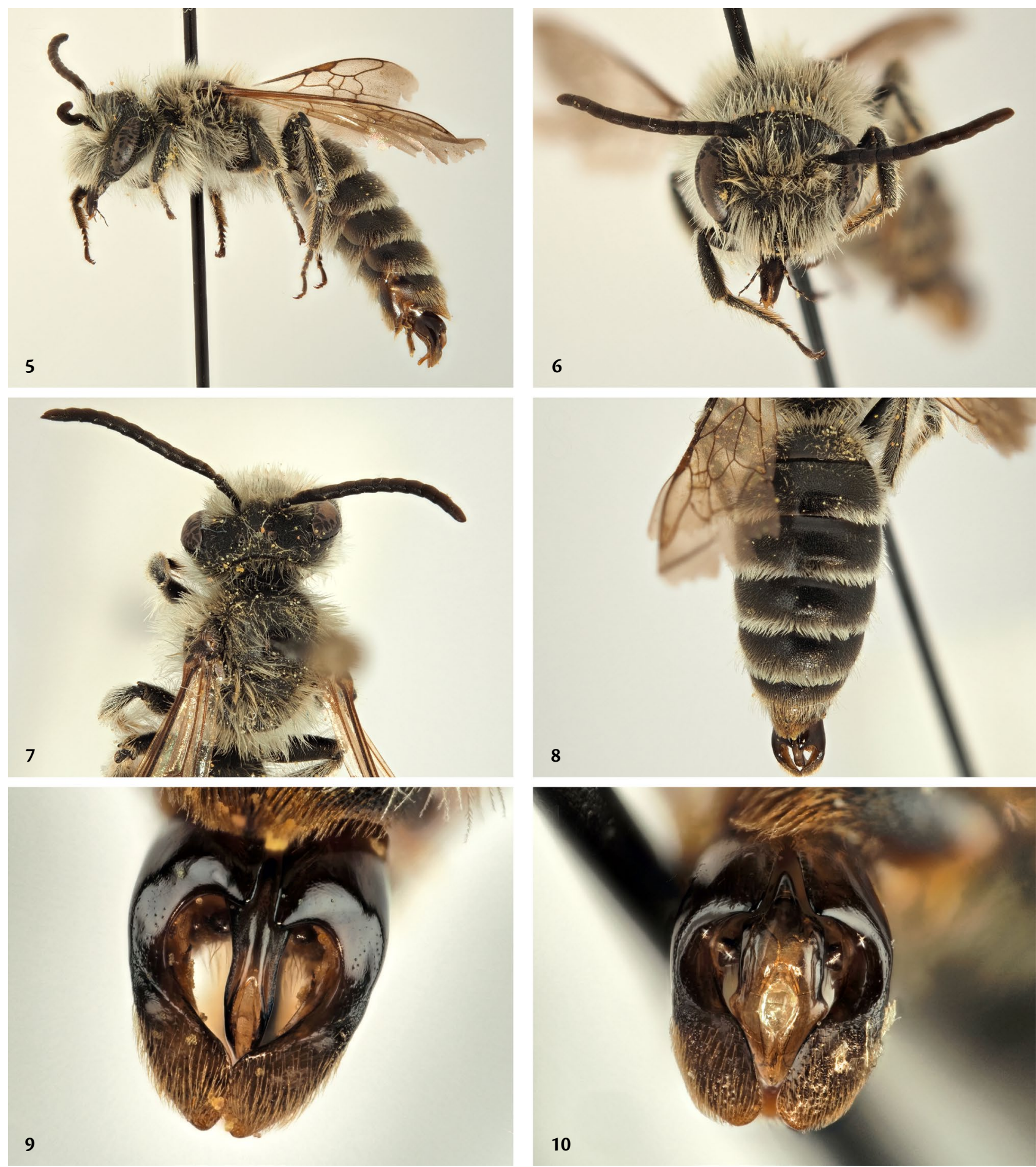

Figures 5-10. Andrena contracta spec. nov. 5. Male profile. 6. Male face. 7. Male scutum. 8. Male terga. 9. Male genitalia. Andrena intermedia THOMSON, 1870. 10. Male genitalia. Photos T. J. WOOD.

further south than the Sistema Ibérico (see map in GUSENLEITNER \& SCHWARZ, 2002). Andrena contracta is found above the treeline in more exposed environments (figure 12), and was recorded at Lotus cf. corniculatus, Trifolium cf. repens, and Anthyllis vulneraria. No female specimens had pollen in their scopae, but the species is expected to be a specialist of Fabaceae since this is the strategy pursued by almost all studied Taeniandrena species, those that are not specialists having at least a strong preference for this family (WESTRICH, 1989; T. J. WOOD, unpublished data).
Genetic sequences were generated as part of a revision of West Palearctic Taeniandrena (C. PRAZ \& T. J. WOOD, in prep.), and place $A$. contracta in the group of A. gelriae VAN DER VECHT, 1927, along with $A$. intermedia and related species.

\section{Etymology}

Feminine nominative singular of contractus (close, narrow, restricted, pinched), referring to the very narrow penis valve of the male. 

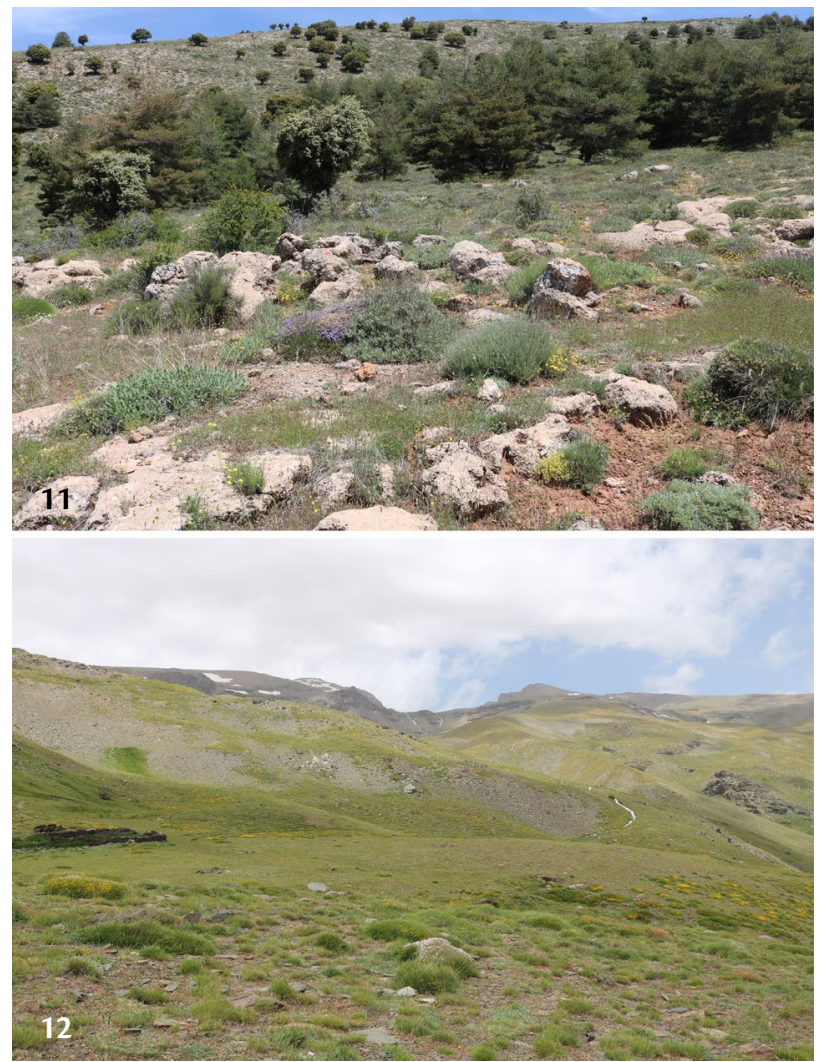

Figures 11-12. 11. Sierra Nevada, Jardín Botánico Hoya de Pedraza environs, c. 1900 m, 9-VI-2021, Andrena intermedia THOMsON, 1870 habitat (subalpine zone). 12. Sierra Nevada, Trevélez, Refugio La Campiñuela, c. 2400 m, 14-VI-2021, Andrena contracta spec. nov. habitat (alpine zone). Photos T. J. Wood.

\section{Other material examined}

Andrena intermedia: Spain: Granada, Sierra Nevada, El Dornajo, 1700 m, 6.VI.2021, 2 ô $\hat{0}, 5$ 우, leg. T. J. Wood, TJWC. Granada, Sierra Nevada, Jardín Botánico Hoya de Pedraza environs, 1900 m, 9.VI.2021, 1 đ, 2 웅, leg. T. J. Wood, TJWC. Granada, Sierra Nevada, Mirador Monte Ahí de Cara, 2100 m, 12.VI.2021, 1 đ̊. leg. T. J. WoOD, TJWC. Granada, Tocón de Quéntar to Camino de Las Ramillas, 1200 m, 11.VI.2021, 4 ổ, 1 \&, leg. T. J. Wood, TJWC. Granada, Sierra de Baza, Prados del Rey, 2000 m, 19.VI.2021, 1 ô, 1 + + , leg. T. J. WoOD, TJWC. Sierra Nevada, b. [bei] Granada, 1500 m, 4.VII.1971, 2 우요, leg. V. HAESELER, OÖLM. Sierra Nevada, b. [bei] Granada, 2300 m, 4.VII.1971, 1 O. leg. V. HAESELER, OÖLM.

\section{Nomada halophila WooD, spec. nov.}

zoosank http://zoobank.org/B0C63A1A-FA6C-4630-82DECEE5D4BE8A77

Holotype. Spain: Málaga, Campillos, Laguna Dulce $\left[37.0489^{\circ} \mathrm{N}\right.$, - 4.8338 W], 4.VI.2021, 1 q, leg. T. J. WoOd. OÖLM

Paratypes. Spain: Málaga, Campillos, Laguna Dulce $\left[37.0489^{\circ} \mathrm{N}\right.$,

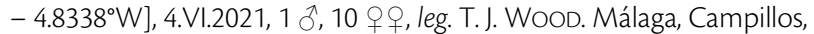
Laguna de Capacete $\left[37.0234^{\circ} \mathrm{N},-4.8253^{\circ} \mathrm{W}\right], 4 . \mathrm{VI} .2021,5$ qo , leg. T. J. WoOD. JSC/OÖLM/TJWC.

\section{Description}

\section{Female}

Body length: 6-7 mm (figure 13). Head: 1.4 times wider than long (figure 15). Head predominantly red, only apex of mandibles, two patches on frons extending to inter-ocellar area, posterior part of gena marked with black. Labrum two times broader than long, with small tooth centrally in basal half, separated from basal margin by 2 diameters of tooth's basal width, apical margin with small row of blunt teeth. Malar area linear; mandibles unidentate, apically sharply pointed. Entire surface of face densely punctate, punctures separated by $<0.5$ puncture diameters, interspaces shining to weakly shining. Antennae entirely and uniformly redorange, $\mathrm{A} 3$ below approximately $3 / 4$ length $A 4$. Ocelloccipital distance equals 2 times diameter of lateral ocellus. Mesosoma: Mesosoma black, with red maculations on scutum (two broad longitudinal stripes occupying most of dorsal surface, with small internal black mark, figure 17), pronotum, pronotal lobes, scutellum, metapostnotum, majority of surface of episternum. Scutum very densely punctured, punctures separated by $<0.5$ puncture diameters, interspaces weakly shining; dorsally scutum with very short, sparse and semi-adpressed golden hairs. Scutellum centrally weakly emarginate, forming two humps. Propodeum laterally with short, white, erect, and weakly plumose hairs. Legs predominantly red, black maculations on femora ventrally, outer face of fore tibia, outer face and hind face of hind tibia. Apex of hind tibia with 4-5 dark, moderately long, moderately spaced spines, with some shorter paler spines behind (figure 14). Wings weakly infuscate, venation dark brown, nervulus strongly postfurcal. Metasoma: Terga predominantly red; T1 black in basal half, red in apical half, impunctate; T2 entirely red, T3-5 red with progressively greater black makings laterally and basally (figure 19). T2-4 evenly punctate on disc, punctures separated by 1 puncture diameter, tergal margins impunctate, occupying slightly less than half visible tergal area, delicately shagreened, weakly shining. T5 uniformly punctate, no margin visible, apically with thick band of extremely dense short white hairs, forming terminal fringe. Pygidial plate with thin raised margin, thus appearing slightly concave, evenly rounded apically, centrally finely shagreened, impunctate.

\section{Male}

Body length: $6 \mathrm{~mm}$ (figure 21). Head: 1.3 times wider than long (figure 22). Head dark, yellow maculations on apical part of clypeus, malar space, mandibles basally, labrum laterally, centre of labrum dark. Labrum two times broader than long, with small tooth centrally in basal half, separated from basal margin by 1 diameter of tooth's basal width, apical margin with small row of blunt teeth. Malar area linear, mandibles unidentate, apically sharply pointed, with small tubercle on outer face (figure 25). Head structurally as in female, no eye plates present. Antennae dark orange brown, A3-13 light orange below, A7-13 light orange above. A4-7 with pointed tubercle on rear face, A5-6 with tiny rounded tubercle hidden below, visible in hind view. Mesosoma: Mesosoma black, scutellum with two red maculations, episternum with small reddish maculation, pronotal lobes brownish-orange (figure 23). Episternum laterally with short weakly plumose hairs, slightly exceeding width of lateral ocellus; scutum with erect whitish hairs, approaching half of length of scape. Propodeum as in female. Legs as in female, but dark areas much more extensive, covering majority of hind femora. Metasoma: Terga as in female, but with fine inconspicuous punctures extending onto tergal margins, punctures separated by 2-3 puncture diameters (figure 24). Pygidial plate large, evenly rounded triangular, with thin raised margin, internal surface densely punctate, punctures separated by 0.5 puncture diameters. 

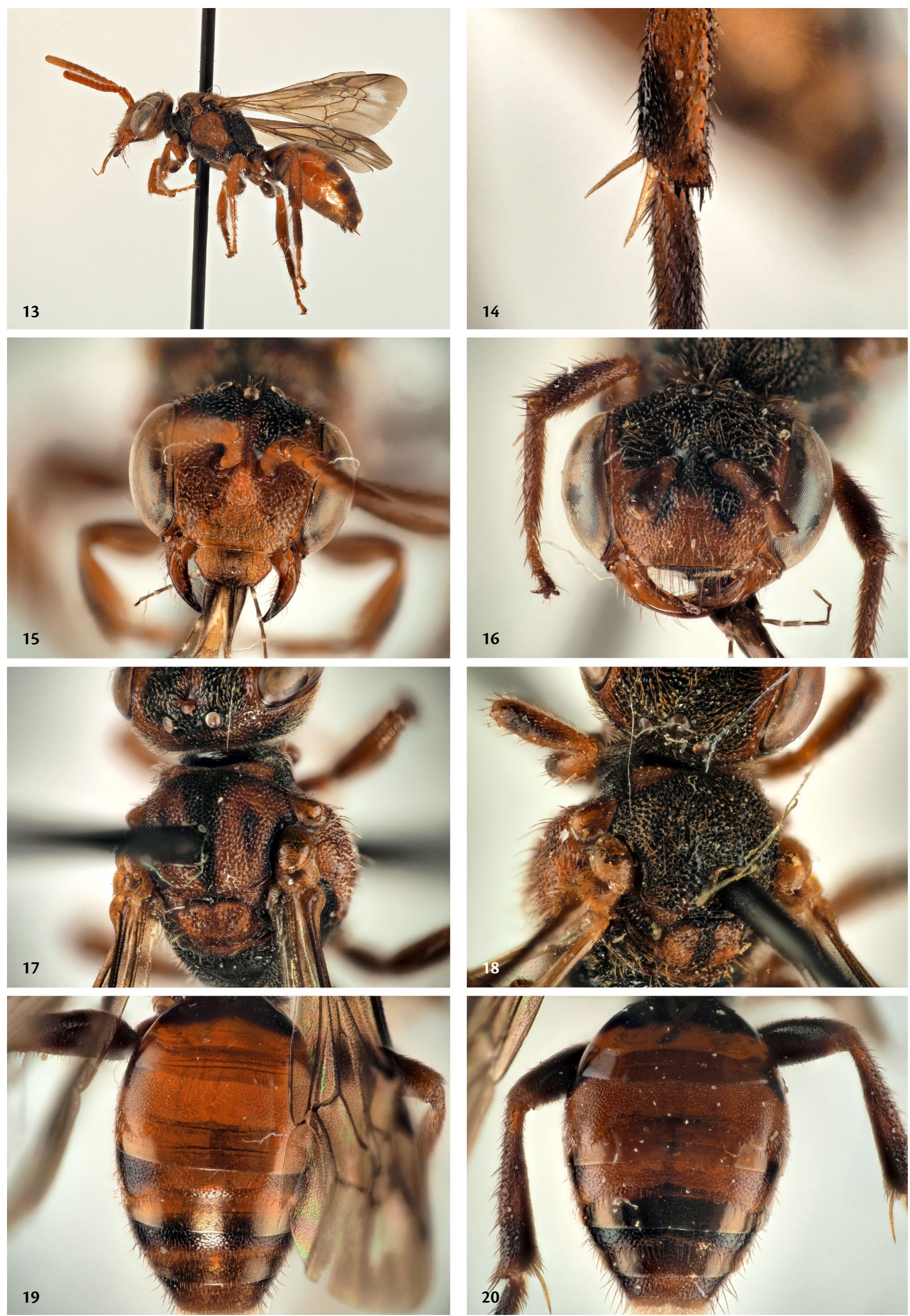

Figures 13-20. 13-15, 17, 19. Nomada halophila spec. nov. 13. Female profile. 14. Female hind tibia detail. 15. Female face. 17. Female scutum. 19. Female terga. 16, 18, 20. Nomada tridentirostris DouRS, 1873. 16. Female face. 18. Female scutum. 20. Female terga. Photos T. J. WoOD. 

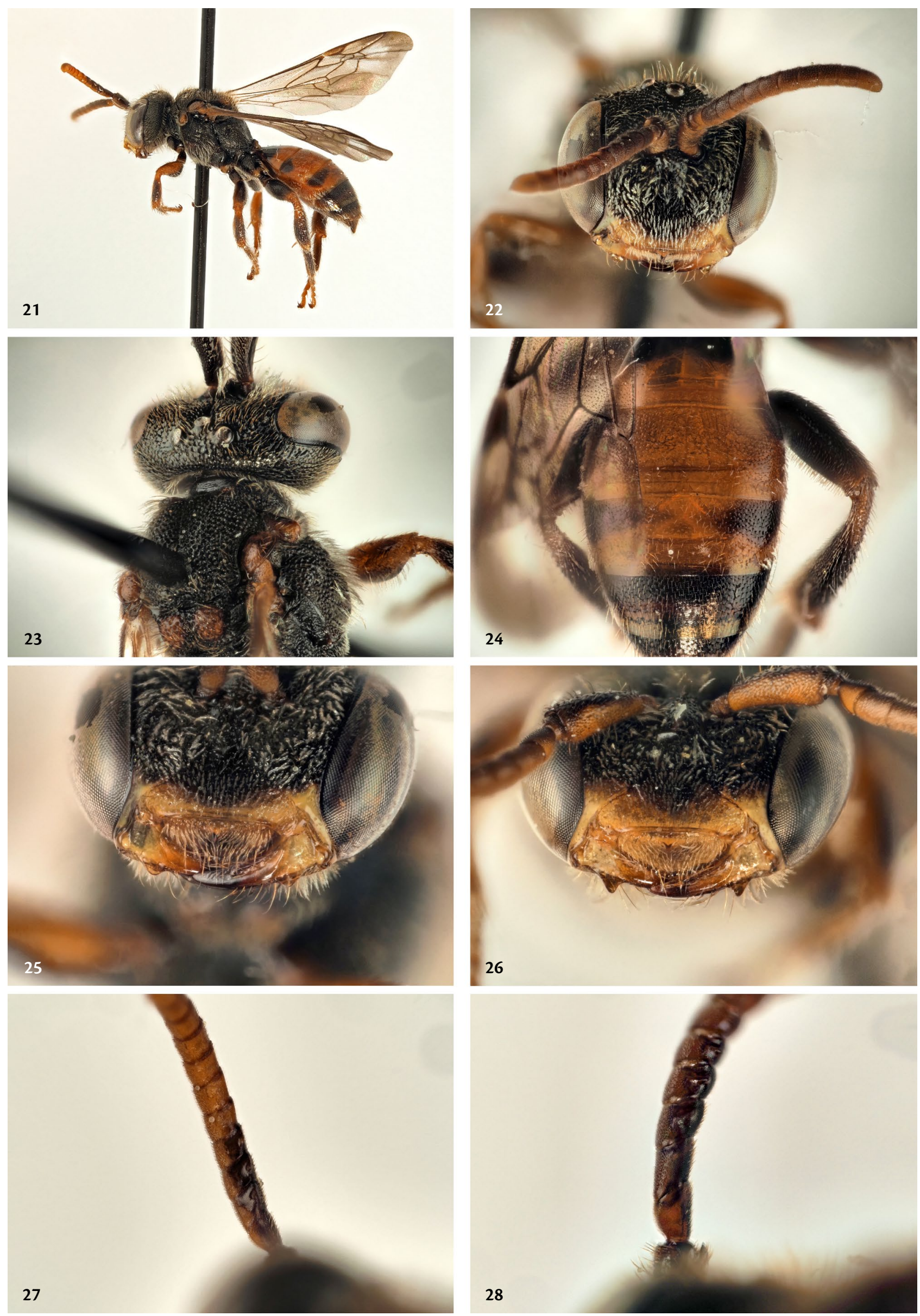

26

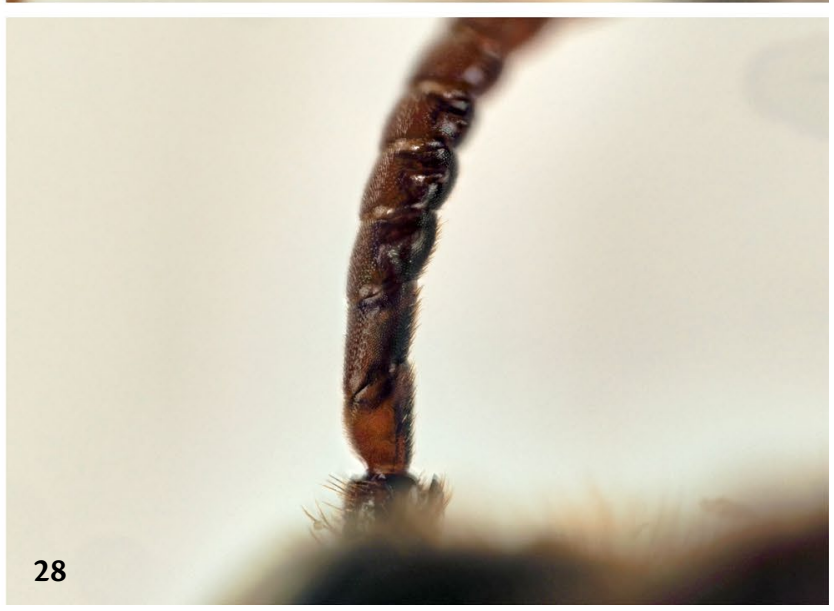

Figures 21-28. 21-25, 27. Nomada halophila spec. nov. 21. Male profile. 22. Male face. 23. Male scutum. 24. Male terga. 25. Male mandible detail. 27. Male antennae hind face detail. 26. Nomada tridentirostris DOURS, 1873. Male mandible detail. 28. Nomada stigma FABRICIUS, 1805. Male antennae hind face detail. Photos T. J. WoOD. 

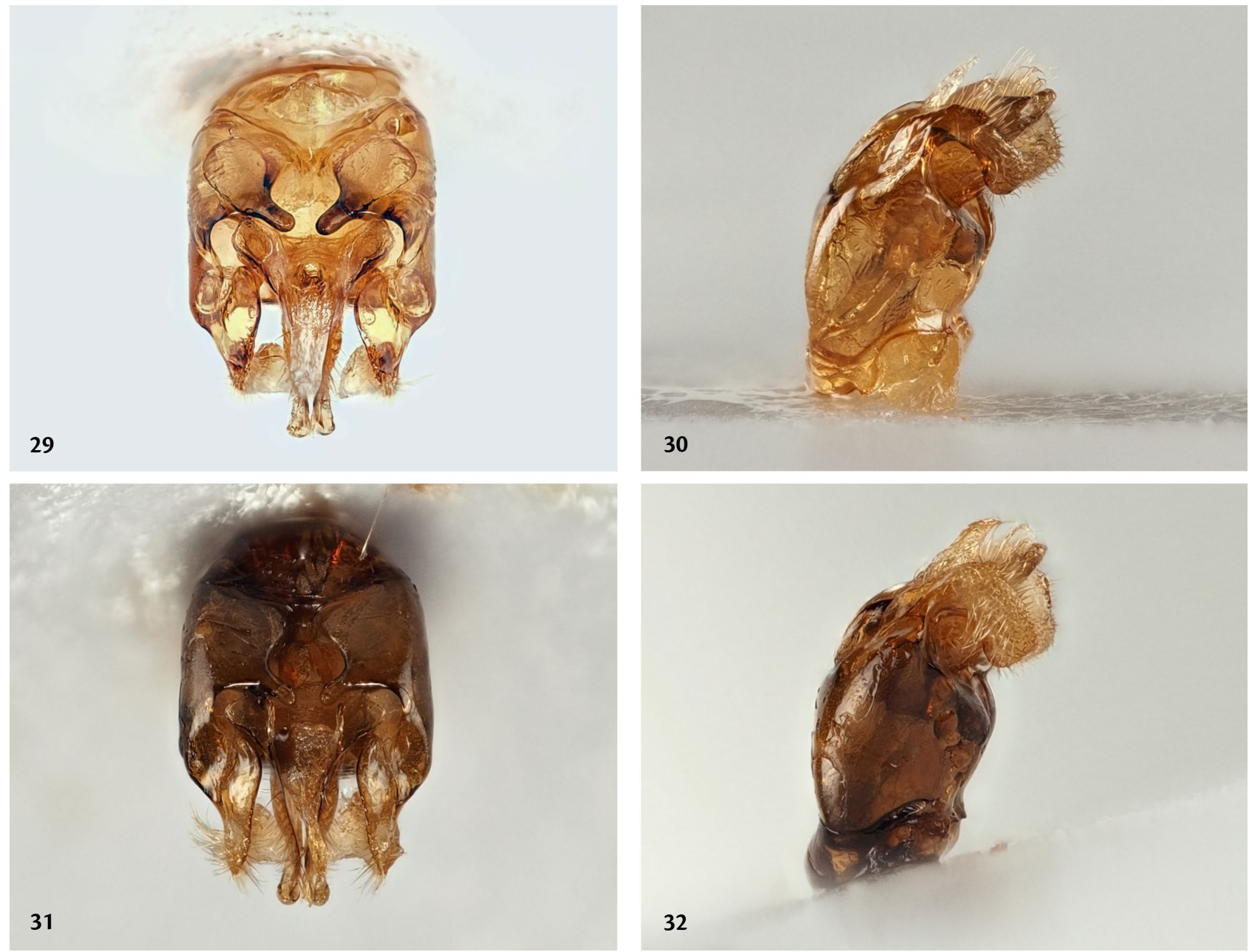

Figures 29-32. 29-30. Nomada halophila spec. nov. 29. Male genitalia, dorsal view. 30. Male genitalia, lateral view. 31-32. Nomada tridentirostris DOURS, 1873. 31. Male genitalia, dorsal view. 32. Male genitalia, lateral view. Photos T. J. WoOD.

Genitalia compact, gonocoxae with large rounded teeth, penis valve basally wide, narrowing medially, apically terminating in two small, rounded lobes (figure 29). Gonostyli broad basally, narrowing medially, elongate, projecting ventrally at a rounded, 90-degree angle (figure 30).

\section{Diagnosis}

Males can be recognised by the combination of characters: mandibles unidentate, hind tibiae with spines apically, labrum without impunctate strip basally, malar area short, sharp carina between antennal insertions, A3 significantly shorter than A4, some antennal segments with pointed tubercles on their hind face, labrum with a short tooth near the base, and mandibles with a tubercle on their outer face. In the key of SMIT (2018), this puts it close to Nomada tridentirostris DOURS, 1873 and N. stigma FABRICIUS, 1805 (couplet 74). It can be separated from N. stigma because the pointed tubercles on the hind face of the antennal segments are composed of two parts (as in N. tridentirostris), not a single transverse carina (figures 27-28), and because the gonostyli are elongate and project ventrally (figure 30 ), as in $N$. tridentirostris. Nomada stigma is also a considerably larger species (see notes on host preference below) with males at 8-10 $\mathrm{mm}$ in length, compared to $6-7 \mathrm{~mm}$ for $\mathrm{N}$. tridentirostris and N. halophila. The shape of the genitalia is very close to $N$. tridentirostris, but can be separated by the comparatively narrower blades of the gonostyli in lateral view, these not noticeably wider than the basal section of the gonostyli (figure 30). In contrast, in N. tridentirostris the blades of the gonostyli are comparatively wide, clearly wider than the basal sections of the gonostyli which are themselves noticeably constricted (figure 32). Nomada halophila can also be separated from $N$. tridentirostris based on external morphology, because the mandibular tubercles are short, not long (figures 25-26).

Females can be recognised by many of the same characters: mandibles unidentate, hind tibiae with simple spines apically, labrum without impunctate strip basally, malar area short, sharp carina between antennal insertions, A3 significantly shorter than A4, mandibles apically pointed, labrum with a tooth close to the base, T1 impunctate, T2-5 with distinct well marked punctures on the disc, margins of terga wide and shining, impunctate. This places it very close to $N$. tridentirostris, but it can be separated by the slightly more central position of the labral tooth (separated from basal margin of labrum by two diameters of the tooth's basal width, in N. tridentirostris the labral tooth is separated from the basal margin of the labrum by a single diameter of the tooth's basal width) and by the more extensive red colouration of the labrum, frons, and scutum, whereas all these areas are much darker to uniformly black in $N$. tridentirostris (figures 15-20). There is no difference in size. 


\section{Ecology and distribution}

Nomada halophila was found at the edge of two saline lagoons at nest sites of Andrena juliana WOOD, 2021 that was recently described from saline estuary areas in southern Spain (Málaga) and Portugal (Algarve) (WooD et al., 2021). As hypothesised by WOOD et al. (2021), Andrena juliana can be confirmed as a halophile, being found abundantly at Laguna de Capacete (figure 33) with an aggregation comprising thousands of nests (figures 34-35). It was also found further east, in Murcia province (see figure 38, other material examined), giving it a distribution stretching across the lower part of the Iberian Peninsula. Pollen removed from 35 females from two localities demonstrates that A. juliana is polylectic with a strong preference for Apiaceae (figures 36-37, table I).

Table I. Host-plant spectrum and host range of Andrena juliana WoOD, 2021. $n$ : total number of pollen loads. N: number of pollen loads from different localities. Plant taxa: API: Apiaceae, CIS: Cistaceae, FRA: Frankeniaceae.

\begin{tabular}{|l|c|c|c|c|c|c|}
\hline & $n$ & N & \% of pollen grains & $\begin{array}{c}\text { \% pure loads of } \\
\text { preferred host }\end{array}$ & $\begin{array}{c}\text { \% loads with } \\
\text { preferred host }\end{array}$ & Host range \\
\hline Andrena juliana & 35 & 2 & API 82.6, FRA 13.1, CIS 2.8, others 1.4 & $74.3 \%$ & $82.9 \%$ & $\begin{array}{c}\text { Polylectic with a strong } \\
\text { preference for Apiaceae }\end{array}$ \\
\hline
\end{tabular}
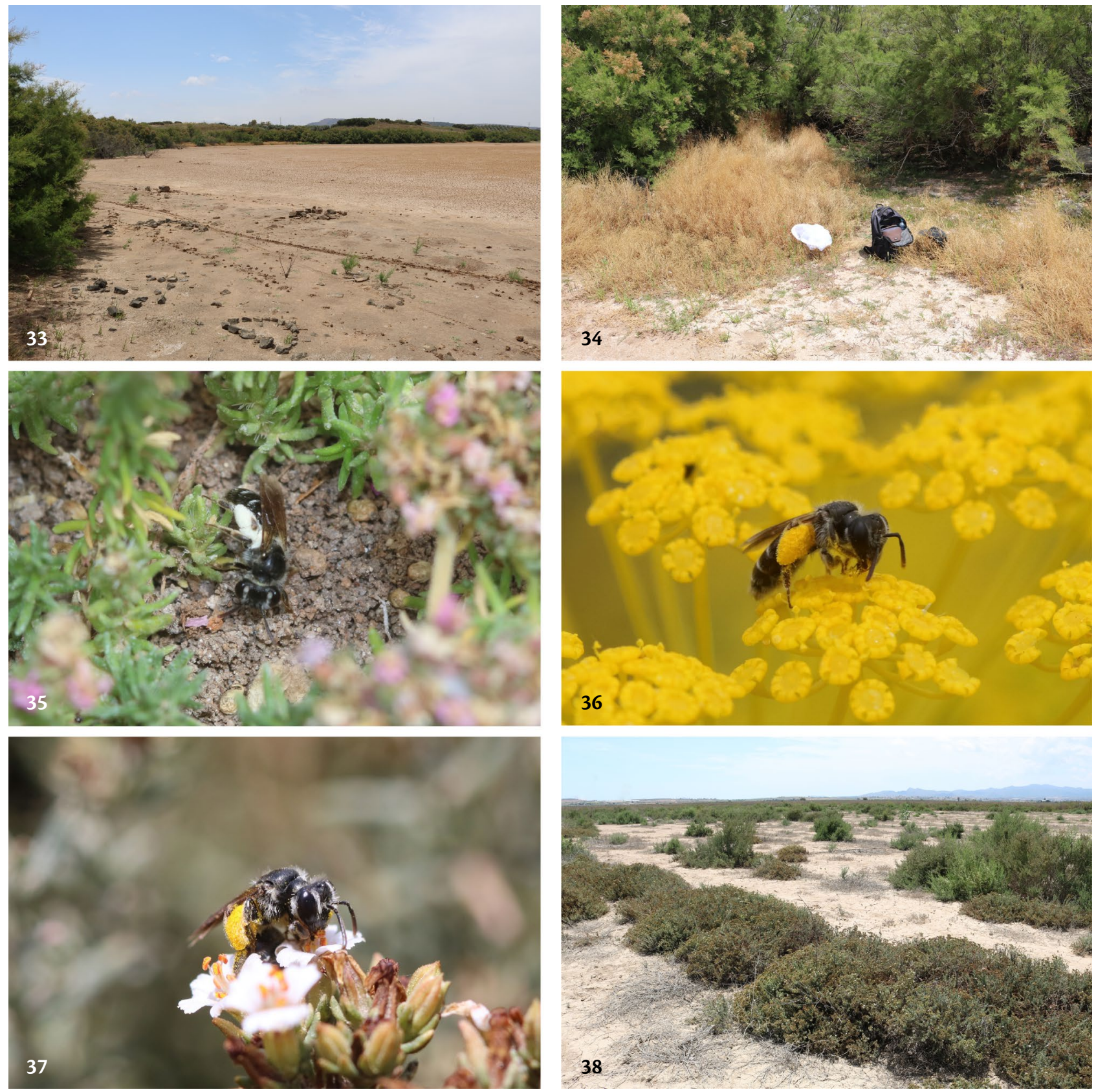

Figures 33-38. Andrena juliana WoOD, 2021. Málaga, Laguna Capacete, 4.VI.2021. 33. View of dried lagoon bed. 34. Nesting aggregation at edge of dry lagoon. 35. Nest searching female. 36. Female gathering pollen from Apiaceae. | Murcia, Totana, Saladares del Guadalentín, 17.VI.2021. 37. Female collecting pollen from Frankenia laevis. 38. Saline habitat with F. laevis. Photos T. J. Wood. 
Nomada halophila was the only Nomada species present at the nesting aggregation found at Laguna de Capacete. Here, along with A. juliana females, it moved low over the ground searching for nest entrances. Nests were built at the base of vegetation, most typically at the base of stems of now-dead grass (figure 34) or of Frankenia laevis (vegetation in figure 35). In the same way as in the nests of the unrelated A. (Leucandrena) barbilabris (KIRBY, 1802), the entrances of A. juliana nests self-seal with loose sand after passage, meaning that females spend a considerable time searching for the correct location before burrowing down and disappearing.

Whilst not proven, this potential host association is highly suggestive. The only other Nomada species present at the Laguna de Capacete site (but not the A. juliana aggregation) was N. minuscula NOSKIEWICZ, 1930 which was attacking nests of Lasioglossum minutissimum (KIRBY, 1802). Nomada tridentirostris attacks $A$. (Cryptandrena) ventricosa DoURS, 1873 (KOCOUREK, 1966; SMIT, 2018), and N. stigma attacks members of the subgenus Holandrena PÉREZ, 1890 (MANDERY et al., 2008), these larger Andrena (Holandrena) explaining the size difference between the two species. The use of $A$. (Notandrena) juliana introduces a third subgenus of Andrena hosts, all three being found in the lower (younger) half of the Andrena phylogeny but which are generally unrelated (PISANTY et al., 2022). Phylogenetic work is needed to establish if there is a close evolutionary relationship between these Nomada species or not, though the very similar genitalia suggest that $N$. halophila and $N$. tridentirostris are indeed closely related.
More broadly, the associated bee fauna at Laguna de Capacete contained other halophilous species, most interestingly Lasioglossum orihuleicum (BLÜTHGEN, 1924) and Camptopoeum baldocki WOOD \& CROSS, 2017, a strong halophile (WOOD \& CROSS, 2017) that was very recently added to the Spanish fauna from a nearby site (ÁlVAREZ FIDALGO, 2021). In addition to saline lagoons in Málaga province, $N$. halophila could be found in potentially in any other location where A. juliana has been recorded, including in Portugal (WoOD et al., 2021).

\section{Etymology}

Composed of the Greek prefix halo- (salt) and phila (friendship) because of its habitat choice and host association with $A$. juliana, a species seemingly bound to saline habitats.

\section{Other material examined}

Andrena juliana: Spain: Málaga, Campillos, Laguna Dulce, $9 \hat{\jmath} \hat{\jmath}, 2$ 우, leg. T.J. Wood, OÖLM/TJWC. Málaga, Campillos, Laguna de Capacete,

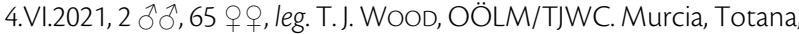
Saladares del Guadalentín, 17.VI.2021, 1 §, 8 q 9 , leg. T. J. WoOD, TJWC.

Nomada tridentirostris: Croatia: Istrien, Rovinj, 2 km SE, 30.VI.1996, 1 ô, leg. J. Gusenleitner, det. M. SChwarz, OÖLM. France: Var, Flessans-sur-Issole, Lac Redon, 290 m, 16.V.1997, 1 \&, leg. J.-M. BRULET, det. M. SChWARZ, UMONS. Var, Flessans-sur-Issole, Blanquefort, $260 \mathrm{~m}$, 15.V.1992, 1 q, leg. C. Coutelere, det. M. SChwarz, UMONS. Var, Gonfaron, les Ribas, 14-16.V.1996, 3 웅, leg. NDONGO \& S. DUPONT, det. M. SChWARZ, UMONS. Italy: Umbria, Amelia (TR), 20 km W Terni, 1.VI.1991, 1 q, leg. J. GuSENLEITNER, det. M. SCHWARZ, OÖLM. Turkey: Kilyos, 26.V.1964, 1 \%, leg. J. GuSENLEITNER, det. M. SCHWARZ, OÖLM.

\section{DISCUSSION}

These discoveries add to the growing body of evidence (MülleR, 2012; ORTIZ-SÁNCHEZ \& PAULY, 2017; RADCHENKO, 2017; WOOD \& CROSS, 2017; KUHLMANN \& SMIT, 2018; LE GOFF \& GONÇALVES, 2018; SMIT, 2018; WOOD et al., 2020; WOOD et al., 2021) that our knowledge of the Spanish bee fauna is still incomplete, despite the European bee fauna as a whole having the longest history of taxonomic and ecological study. They also re-emphasise the remarkable nature of the Sierra Nevada mountain range, and the endemic insect fauna it supports. Further expeditions in unusual or little-visited habitats across Spain and more widely in southern Europe and northern Africa are likely to continue to add to the size of the bee fauna in these regions. 


\section{ACKNOWLEDGEMENTS}

My thanks go to Sara ReVERTÉ SAIz (Mons) for assistance with Spanish when applying for a collection permit, and to Blanca RAMOS, José EnRIQUE Granados Torres, and Natividad Jiménez HernÁndez (Parque Nacional y Parque Natural de Sierra Nevada) for help with permits and access to the Sierra Nevada. All specimens from the Sierra Nevada National Park were collected under permit number 202199901002937. My thanks go also to Esther OCKERMÜLLER (Linz) for access to the collection and loan of comparative Nomada material, to Jakub STRAKA for helpful conversation about Nomada taxonomy, and to Benoît GESLIN, Jan SMIT and Franciso Javier ORTIZ-SÁNCHEZ for comments that improved to the manuscript. The author is supported by an F.R.S.-FNRS fellowship (Chargé de recherches). 


\section{REFERENCES}

Álvarez Fidalgo, P. (2021). First record of Camptopoeum (Camptopoeum) baldocki WOOD \& CROSS, 2017 from Spain (Hymenoptera, Apoidea, Andrenidae). Boletín de la Sociedad Entomológica Aragonesa (S.E.A.), 68: 433-434.

BUIRA, A., F. J. CABEZAS \& C. AEDo (2020). Disentangling ecological traits related to plant endemism, rarity and conservation status in the Iberian Peninsula. Biodiversity and Conservation, 29(6): 19371958. https://doi.org/10.1007/s10531-020-01957-z

Ghisbain, G., B. Martinet, T. J. Wood, K. Przybyla, D. Cejas, M. Gérard, P. Rasmont, A. Monfared, I. Valterová \& D. Michez (2021). A worthy conservation target? Revising the status of the rarest bumblebee of Europe. Insect Conservation and Diversity, 14(5): 661-674. https://doi.org/10.1111/icad.12500

Gusenleitner, F. \& M. Schwarz (2002). Weltweite Checkliste der Bienengattung Andrena mit Bemerkungen und Ergänzungen zu paläarktischen Arten (Hymenoptera, Apidae, Andreninae, Andrena). Entomofauna, Zeitschrift für Entomologie, Supplement 10: 1-1280. https://www.zobodat.at/pdf/ENTS_S12_00011280.pdf [accessed 15 October 2021]

KOCOUREK, M. (1966). Prodromus der Hymenopteren der Tschechoslowakei. Pars 9: Apoidea, 1. Acta Faunistica Entomologica Musei Nationalis Pragae Supplementum 2, 12: 1122. https://www.aemnp.eu/data/article-136/117-2_0_1.pdf [accessed 15 October 2021]

KUHLMANN, M. \& J. SMIT (2018). Description of a new bee species from Spain, Colletes jansmiti KUHLMANN nov.sp., with a key to the females of the C. albomaculatus-group (Hymenoptera: Colletidae). Linzer biologische Beiträge, 50(2): 1249-1254. https://www.zobodat.at/pdf/LBB_0050_2_1249-1254.pdf [accessed 15 October 2021]

Le Goff, G. \& A. R. Gonçalves (2018). Une nouvelle espèce de Protosmia DUCKE, 1900 découverte au Portugal: Protosmia (Protosmia) lusitanica n.sp. (Apoidea, Megachilidae, Osmiini). Entomofauna, 39(1): 187-191.

https://www.zobodat.at/pdf/ENT_0039_0187-0191.pdf [accessed 15 October 2021]

MANDERY, K., J. KOSUCH, \& J. SCHUBERTH (2008). Untersuchungsergebnisse zum Artstatus von Andrena decipiens SCHENCK, 1861, Andrena flavilabris SCHENCK, 1874, und ihrem gemeinsamen Brutparasiten Nomada stigma FABRICIUS, 1804 (Hymenoptera: Apidae). Nachrichtenblatt der Bayerischen Entomologen, 57(1/2): 30-41.

https://www.zobodat.at/pdf/NachBIBayEnt_057_0030-0041.pdf [accessed 15 October 2021]

MiCHener, C. D. (2007). The Bees of the World. 2nd edition. The Johns Hopkins University Press, Baltimore (United States of America), $953 \mathrm{pp}$.

MicheZ, D. \& C. EARDLEY (2007). Monographic revision of the bee genus Melitta KIRBY 1802 (Hymenoptera: Apoidea: Melittidae), Annales de la Société Entomologique de France, 43(4): 379-440. https://doi.org/10.1080/00379271.2007.10697535

MÜLLER, A. \& M. KUHLMANN (2008). Pollen hosts of western palaearctic bees of the genus Colletes (Hymenoptera: Colletidae): the Asteraceae paradox. Biological Journal of the Linnean Society, 95(4): 719-733. https://doi.org/10.1111/j.1095-8312.2008.01113.x

MülLER, A. (2012). New European bee species of the tribe Osmiini (Hymenoptera: Apoidea: Megachilidae).Zootaxa, 3355(1): 29-50. http://doi.org/10.11646/zootaxa.3355.1.2
Ortiz-SÁnchez, F. J., C. Ornosa \& F. Torres (2013). Las Abejas (Hymenoptera: Apoidea). pp. 375-390. In: F. RUANO, M. TIERNO DE FIGUEROA \& A. TINAUT (ed.). Los Insectos de Sierra Nevada. 200 años de historia. Volumen 2. Asociación Española de Entomología, Granada (Spain), 528 pp.

OrTiz-SÁnChEZ, F.J. \& PaulY, A. (2017). Contribution à la connaissance des Halictinae d'Espagne, avec un atlas des espèces de la Péninsule Ibérique (Hymenoptera: Apoidea: Halictidae). Belgian Journal of Entomology, 54: 1-92.

https://www.researchgate.net/publication/320107044_Contribu tion_a_la_connaissance_des_Halictinae_d\%27Espagne_avec_u n_atlas_des_especes_de_la_Peninsule_Iberique_Hymenoptera _Apoidea_Halictidae [accessed 15 October 2021]

Ortiz-SÁncheZ, F. J. (2020). Checklist de Fauna Ibérica. Serie Anthophila (Insecta: Hymenoptera: Apoidea) en la península ibérica e islas Baleares (edición 2020). In: M. A. RAMOS \& M. SÁNCHEZ RUIZ (ed.). Documentos Fauna Ibérica 14. Museo Nacional de Ciencias Naturales, CSIC. Madrid: 2 (sn) +83 pp. http://www.fauna-iberica.mncn.csic.es/publicaciones/dfi/dfi0014.pdf

Pisanty, G., R. Richter, T. Martin, J. Dettman \& S. Cardinal (2022). Molecular phylogeny, historical biogeography and revised classification of andrenine bees (Hymenoptera: Andrenidae) Molecular Phylogenetics and Evolution, 170, in press. https://doi.org/10.1016/j.ympev.2021.107151

RADCHENKO, V.G. (2017). A new bee species of the genus Dasypoda LATREILle (Hymenoptera, Apoidea) from Portugal with comparative remarks on the subgenus Heterodasypoda MICHEZ. Zootaxa, 4350(1): 164-176.

https://doi.org/10.11646/zootaxa.4350.1.10

RuAno, F., M. TIERNO de Figueroa \& A. Tinaut (ed.) (2013). Los insectos de Sierra Nevada. 200 años de historia. Asociación Española de Entomología, Granada (Spain), 2 vols., $544+528$ pp.

SMIT, J. (2018). Identification key to the European species of the bee genus Nomada SCOPOLI, 1770 (Hymenoptera: Apidae), including 23 new species. Entomofauna Monographie 3: 1-253. https://www.zobodat.at/pdf/ENT_M3_0001-0253.pdf [accessed 15 October 2021]

WESTRICH, P. (1989). Die Wildbienen Baden-Württembergs. Verlag Eugen Ulmer, Stuttgart (Germany). 2 vols., 972 pp.

Wood, T. J. \& I. Cross (2017). Camptopoeum (Camptopoeum) baldocki spec. nov., a new panurgine bee species from Portugal and a description of the male of Flavipanurgus fuzetus PATINY (Andrenidae: Panurginae). Zootaxa, 4254(2): 285-293. https://doi.org/10.11646/zootaxa.4254.2.9

WOOD, T. J. \& S. P. M. ROBERTS (2018). Constrained patterns of pollen use in Nearctic Andrena (Hymenoptera: Andrenidae) compared with their Palaearctic counterparts. Biological Journal of the Linnean Society, 124(4): 732-746. https://doi.org/10.1093/biolinnean/bly080

WOOD, T. J., I. CROSS \& D. W. BALDOCK (2020). Updates to the bee fauna of Portugal with the description of three new Iberian Andrena species (Hymenoptera: Apoidea: Anthophila). Zootaxa, 4790(2): 201-228. https://doi.org/10.11646/zootaxa.4790.2.1

Wood, T. J., G. GHISBAIN, D. MicheZ \& C. Praz (2021). Revisions to the faunas of Andrena of the Iberian Peninsula and Morocco with the descriptions of four new species (Hymenoptera: Andrenidae) European Journal of Taxonomy, 758: 147-193. https://doi.org/10.5852/ejt.2021.758.1431

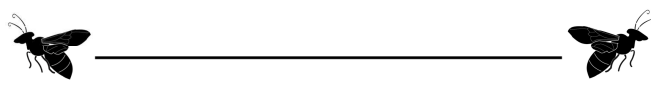

